\section{The tyranny of auditors}

SIR - The US Secretary of Energy's decision to split the Superconducting Super Collider (SSC) project into separate construction and science components is ill-advised, no matter how politically expedient it may be (Nature 364, 567; 1993). The building of a major facility is usually subject to compromise at some stage when decisions have to be made in response to some unexpected difficulty or cost overrun. Now it would seem that the accountants will have the final word when such decisions have to be made. Thus, when it is eventually completed, it is highly likely that the SSC will differ in some important respect from what the scientists would have chosen within the budgetary limits.

Nowadays, scientists' overriding concern seems to be not so much what they want to do but with what can be done with the available equipment that has not yet been done. In these circumstances, it should not be surprising that scientists will push for ever more expensive equipment as they strive for the competitiveness their auditors expect of them. I believe that our best hope of escaping from the spiralling costs imposed by the tyranny of the auditor lies with the politicians and other controllers of the purse strings who can see that the more constraints they impose on basic researchers the more predictable (and expensive) the results will be.

Signs are sometimes displayed in shops along the lines - "I have reached an agreement with the banks that they will not sell vegetables. In return I have agreed not to cash cheques." The Secretary of Energy's decision is probably irrevocable, but if the scientists promise not to audit perhaps she can extract a reciprocal promise from the accounts?

\section{D.W. Braben}

Venture Research International Ltd, 13-14 Mount End,

Theydon Mount,

Epping, Essex CM16 7PS, UK

\section{Allain defended}

SIR - We read with interest Declan Butler's News story (Nature 364, 269; 1993) about the verdict of the French appeal court which has sent Jean-Pierre Allain to prison.

We have known Allain for three decades. From the early 1960s, when he prepared his medical thesis under the supervision of one of us, we recognized both his scientific and his human qualities. On his return from the United States in the mid-1970s, he was charged with the care of the largest concentration of French haemophiliacs at La Queue les-Yvelines.
In many instances, he took the haemophiliacs to his own home and he and his wife, Helen Lee, considered them as their own children. We are unable to imagine that Allain could be the Jekyll and Hyde character portrayed in the French press "avide de sensationnel". We cannot accept that what was a universal error, human in essence, could evolve into a deliberate crime.

Some other writers share the view that he didn't blow the whistle loudly enough to have attention paid to his warnings. In early 1985 , those who held similar posts elsewhere shared Allain's uncertainties at that time.

In Science (260, 1262 \& 261, 422; 1993), it is stated that Allain ranked fourth in the world in citations per paper about research on AIDS. We sincerely hope that the French Supreme Court will decide to hear an appeal.

We share the views expressed by our British colleagues (The Lancet 342, 232$233 ; 1993$ ) and we look forward to Allain's prompt return to transfusion science and medicine in Cambridge.

\section{Jacques P. Caen}

Institut des Vaisseaux et du Sang,

Hôpital Lariboisière,

Paris 75070, France

Peter A. Castaldi

University of Sydney,

Hospital Westmead,

Westmead, NSW2145,

Australia

SIR - Your leading article "Justice unevenly spread in Paris" (Nature 364, 267; 1993) stresses the disadvantages of the sentence for the research community. But Garretta and Allain are primarily physicians who deliberately provided patients with infected material. They were brought to trial not as researchers or commercial managers, but as physicians who should have obeyed the time-honoured medical rule "primum non nocere" ("first of all, do no harm"). The lessons of this trial for the research community are therefore of minor importance compared with the hundreds and maybe the thousands of people contaminated by a deadly disease.

Badrig Mélékian

6 rue Crevaux,

75116 Paris, France

\section{Man and beast}

SIR - Williams et al. (Nature 364 664; 1993 ) protest at the misuse of language in recent publications although they do not allege that the meaning is distorted by the misuse.

For my part, I take particular objection to Williams' misuse of 'animal', which derives from the Latin anima, meaning 'a soul', and should surely be reserved for those of God's creatures that have a soul
- humans. The King James's Bible, printed (1611) before this misuse gained currency, uses 'beast' for what Williams refers to as a 'nonhuman animal'.

In short, tempora mutantur, $\mathrm{Mr}$ Williams. He should realize that language changes, as do languages.

Oliver R. Dearlove

Department of Anaesthesia,

Royal Manchester Children's Hospital, Manchester M25 1HA, UK

SIR - Williams et al. complain that words whose etymology implies human referents are now commonly used in nonhuman contexts. They even raise the possibility that such confusion may stem from a desire for political correctness masking the human/nonhuman distinction.

Two points are worth making. First, if political correctness is indeed an issue, it is important to remember that emphasizing such a distinction is as political as minimizing it. As to which is politically correct and which incorrect, I cannot say; but both are political.

Second, if ignorance is the issue, one might ask why it matters. Languages are dynamic, and meanings and usages change as the years go by. We no longer expect a sophisticated person to be 'impure' or 'adulterated', and the term 'sunrise' is commonly used by those who do not wish to imply that the Sun revolves around the Earth. If I read that there is an epidemic among farm animals, I know exactly what is meant; surely clarity and communicability are more important than etymological niceties, and we should avoid using two words when one will suffice to indicate our meaning?

\section{R. Glynn Owens}

University of Wales, Bangor,

Health Studies Research Division,

Upper School,

St David's Hospital,

Bangor,

Gwynedd LL57 4SL, UK

\section{Not wind but water}

SIR - I am sorry if I should appear to be attempting to sabotage your interesting essay on sand ripples (Nature 364, 385; 1993) but although I have lived by the sea in various places most of my life, I do not actually know any beaches to which it would apply. Deserts, yes indeed, and I suppose also seaside sand dunes, but the typical ripples on the average holiday beach are produced under water and not by the action of wind. These are usually said to represent a standing wave pattern, and certainly it is easy enough to reproduce them in the bath if one has sandy enough feet.

David A. H. Taylor

12 Avenue Road,

Scarborough, Yorkshire Y0125JX, UK 